\title{
Digital Age Literacy in Elementary School
}

\author{
Ermawati Z Nuroh \\ Fakultas Ilmu Keguruan dan Ilmu Pendidikan \\ Universitas Muhammadiyah Sidoarjo \\ Sidoarjo, Indonesia \\ ermawati@umsida.ac.id
}

\author{
Vevy Liansari \\ Fakultas Ilmu Keguruan dan Ilmu Pendidikan \\ Universitas Muhammadiyah Sidoarjo \\ Sidoarjo, Indonesia \\ vevyliansari@umsida.ac.id
}

\begin{abstract}
In the $21^{\text {st }}$ century Literacy can no longer be defined only to read and to write. The impact of rapid development in the information, then the literacy interpreted in several points of view, ranging from basic literacy point of view, science literacy, economic literacy, technology literacy, visual literacy, information literacy, multicultural literacy, to the point of view of global awareness. This is called digital-age literacy or often called multiliteracies. The discussion of literacy widespread, also the more intense teaching literacy in schools, especially in elementary schools, as an effort to produce a literary generation that can build the nation someday. This paper is motivated by the difficulties of schools in the implementation of literacy in elementary schools. This paper will discuss the reality of digitalage literacy in elementary schools which is followed by student difficulties in improving literacy skills caused by inadequate literary practices undertaken by the teachers, the lack of literacy environments, and different parental literacy levels that impact on the lack of literary information obtained by students at their home. Finally the efforts that must be made by various parties coordinate to improve literacy in elementary schools. They are the policy makers are; government, schools, teachers and parents have their respective duties and responsibilities in accordance with their capacity. The facilitation of good literacy practices and a supportive literacy environment. All activities that can bring the desire of students to improve literacy skills in this beloved Indonesia.
\end{abstract} school

Keyword-digital-age literacy; multiliteracies; elementary

\section{INTRODUCTION}

Literacy issues should be given special attention by the Indonesian nation because in recent years the generation of Indonesian nation among other nations tend to be less compete. This is reflected in the comparison of Human Development Index (HDI). Research conducted by the Progress in International Reading Literacy Study (PIRLS) in 2006. PIRLS conducts research on 45 developed and developing countries in the field of reading in fourth grade of elementary schools worldwide under the coordination of The International Association for the Evaluation of Education Achievement (IEA) and achieved results that placed Indonesia in the 41 st position. [1] points out several international studies by describing Indonesian conditions such as research conducted by the Program for International Students Assessment (PISA) on literacy skills (mathematics, science and language) students from various worlds in succession in 2003, 2006, 2009 and 2012. In 2003, language literacy, literacy achievement of Indonesian students was ranked 39th of 40 countries. In 2006 the literacy of Indonesian students' reading was ranked 48th out of 56 countries, in 2009 Indonesian student literacy was ranked 57 th out of 65 countries, and in 2012 Indonesian student literacy was ranked 64 th out of 65 countries.

The results of this study indicate that the literacy skill of Indonesian students representing Indonesian society is generally low, especially in terms of language literacy. Our society has not made the activity of reading and writing as a daily habit. In western societies, reading activity on buses, trains, or airplanes is a common sight. It is very rare in Indonesia. said that this is caused by the [2] people of Indonesia is an a literate community, many people who can read, but have no desire to make the habit of reading as a daily activity. The cause of the low literacy skill (in terms of reading) is a tradition that is still rooted in society. In addition, the primary school system still lacks opportunities for literacy traditions to learners. Teaching model in the classroom delivered with a teacher center approach that positions the students as a listener. Reading activity as a framework based on learning is still rarely applied by the teacher. Therefore, the students are not facilitated towards the development of their literacy so that the literacy culture that produces the literacy generation will be difficult to achieve. In addition to reading skill of Indonesian students is also still relatively low. Depdiknas [3] disclosed some data from the IEA survey of the literacy skill of Indonesian children about $50 \%$ of Primary School of the fourth grade students in six provinces of Primary Education Quality Improvement Project (PEQIP) cannot compose essay. One of the causes of the low reading skill of elementary students in Indonesia that is so many students get lessons memorizing than practicing, including composing essay. Based on the issues raised, so the question arose very basic, that is (1) What causes the language literacy of elementary school students in Sidoarjo not develop? That question will be answered and discussed in this article to produce solutions to problem solving for elementary school students in improving literacy skills.

\section{MULTI LITERATION IN ELEMENTARY SCHOOL}

As we have seen and understood together, literacy is defined as a literate and literary skill, often referred to as literacy. But in the context of the 21 st century, literacy experiences an expansion of meaning beyond reading and 
writing. The high literacy skill is the skill that allows people to read the world not just words, sentences, paragraphs, or a discourse. Literacy involves the use of various forms of communication that provide further and greater opportunities to advance oneself, family, community, and nation. Literacy helps understand the world and reveals identity, idea, and culture. In other words literacy is no longer a single meaning but contains multiple meanings (multiliteracies). In multiliteracies, literacy can mean technological literacy, politics, critical thinking, and sensitive to the environment. A person can only be said to be literate if he is able to understand something by reading and doing something based on his reading comprehension. [4] states that "The development of literacy is part of a larger process of semiotic development which includes gestures, make-believe things, drawing, talking about storybooks, explaining road signs or food labels, etc. Mustafa explains "the literacy that develops in children not only in reading and writing, but can be translated into various or varied meanings, often called multiliteracies".

Multiliteracies obtained by elementary students includes a literacy skill called Digital-Age Literacy. The literacy skills that must be programmed are as follows [5] :

a. Basic Literacy; Language proficiency (in English) and numeracy at levels necessary to function on the job and in society to achieve one's goals and to develop one's knowledge and potential in this Digital Age.

b. Scientific Literacy: Knowledge and understanding of the scientific concepts and processes required for personal decision making, participation in civic and cultural affairs, and economic productivity.

c. Economic Literacy: The ability to identify economic problems, alternatives, costs, and benefits; analyze the incentives at work in economic situations; examine the consequences of changes in economic conditions and public policies; collect and organize economic evidence; and weigh costs against benefits.

d. Technological Literacy: Knowledge about what technology is, how it works, what purposes it can serve, and how it can be used efficiently and effectively to achieve specific goals.

e. Visual Literacy: The ability to interpret, use, appreciate, and create images and video using both conventional and 21 st century media in ways that advance thinking, decision making, communication, and learning.

f. Information Literacy: The ability to evaluate information across a range of media; recognize when information is needed; locate, synthesize, and use information effectively; and accomplish these functions using technology, communication networks, and electronic resources.

g. Multicultural Literacy: The ability to understand and appreciate the similarities and differences in the customs, values, and beliefs of one's own culture and the cultures of others. h. Global Awareness: The recognition and understanding of interrelationships among international organizations, nation-states, public and private economic entities, socio cultural groups, and individuals across the globe.

\section{REALITY OF STUDENT LITERACY LEVEL IN INDONESIA}

The condition of literacy ability of students in Indonesia can be known when compared with some countries in the world. The results of the PISA study on language literacy skills of students from around the world in 2003 the literacy achievement of Indonesian students reading is ranked 39 th out of 40 countries, in 2006 at the 48th rank of 56 countries, in 2009 in the 57 th rank of 65 countries, and 2012 is ranked 64th out of 65 countries. The results of these studies indicate that $25 \%-34 \%$ of Indonesian students enter the first level of literacy. That is, most students from Indonesia still have skill of language literacy in reading learning (learning to read, not reading to learn). Subsequent research was a study conducted by the Progress in International Reading Literacy Study (PIRLS) in 2006. PIRLS undertook a study of 45 developed and developing country in reading in the fourth grade of primary school children worldwide under the coordination of The International Association for the Evaluation of Educational Achievement (IEA) and achieved results Indonesia ranked was 41 st.

Based on a study of children's literacy skills worldwide conducted by Progress in International Reading Literacy Study (PIRLS), it is found that Indonesian students are at the lowest level in Asia. Indonesia with a score of 51.7, below the Philippines with a score of 52.6; Thailand with a score of 65.1; Singapore 74,0; and Hongkong 75.5. Students from Indonesia are only able to answer $30 \%$ of the questions given. International research results show that the Indonesian language literacy skill of Indonesian students representing Indonesian students is generally low.

It is undeniable that in addition to the skill to read, the skill to write students in Indonesia is also still relatively low. This is demonstrated by data from the Ministry of National Education [3] which describes a number of survey data from the IEA on the reading skill of Indonesian children that about $50 \%$ of Primary School of the sixth grade students in six provinces of the Primary Education Quality Improvement Project (PEQIP) cannot compose essay. One of the reasons for the low reading skill of elementary students in Indonesia is that students have more memorization lessons than practicing, including writing. The reality of the language literacy skills of the students in Indonesia above indicates that there are things that should receive extra attention from various parties. Begin policy makers to develop school curriculum that touches literacy skills until teachers, parents, and communities facilitate literary environments in an effort to cultivate literacy in the midst of Indonesian students. 


\section{DIFFICULTIES OF ELEMENTARY SCHOOL STUDENTS IN IMPROVING LITERACY SKILL}

Research on literacy acquisition divided into two categories: the development of early literacy (emergent) and formal literacy training [4]. The development of emergent literacy is the process of learning to read and write informally in the family. Generally, this emergent literacy has features such as literacy demonstrations, interactive cooperation between parents and children, based on daily needs, and taught in a minimal but direct and contextual manner. While formal literacy training refers to teaching that takes place in a variety of formal situations and has been specifically designed with a specific purpose.

Current understanding of the meaning of literacy includes reading, understanding, and appreciating various forms of communication critically, including spoken languge, written communication critically, including spoken language, written communication, communication through print or electric media [6]. [7] suggests that literacy is all of the process of reading and learning which someone learns including four language skills (listening, speaking, reading, and writing). Following Kuder and Hasit opinion, The National Literacy Act [5] defined literacy as "an individual's ability to read, write, and speak in English, and compute and solve problems at the level of proficiency necessary to function on the job and in society to achieve one's goals, and develop one's knowledge and potential". This means that literacy is closely related to the ability of a person to read, write, talk, and process information obtained to solve problems encountered in everyday life. Agreeing with these experts, PIRLS [8] defines literacy as the ability to understand and use the written language required by society or value to the individual. Broader than the above definition, [4] states that literacy in its most fundamental form implies the ability to read, write, and think critically. It means that someone who literacy is someone who reads and writes along with skill to process information obtained from reading and writing activities. From the various definitions above, the authors conclude that literacy can be interpreted as the ability to read, write, view, and design a thing with the ability to think critically that causes a person can communicate effectively and efficiently so as to create meaning [9].

\section{STEPS PROVIDED TO SOLVE ELEMENTARY SCHOOL STUDENT PROBLEMS IN IMPROVING RECEPTIVE-PRODUCTIVE LITERACY CAPACITY}

Surely every problem that arises in this life should be sought solution to the problem is resolved in accordance with expectations. Likewise with the problems of slow literacy development in elementary school students, should be sought and implemented steps appropriate and accurate in solving student problems in improving the ability of language literacy. In this case, all parties related to the students have a role in accordance with the capacity they have in solving the problem of slow progress of literacy in the students. Policymakers, schools and teachers, as well as parents, have their own roles and responsibilities in improving children's literacy skills and taking a strategic role in generating literacy generation for Indonesia.

\section{A. Policy Makers}

Policymakers, in this case the government, should do the following; a) systemically reform in relation to educational issues, both with aspects of the creation of school environments, teachers, curriculum, teaching and learning process activities as well as other supporting aspects, b) the need for widespread opportunities for teachers to develop their competence, be it in academic, professional, social, or personal, by taking care of the needs and opportunities that exist on an ongoing and controlled basis, c) the pre-service and in-service training should be conducted in a more controlled and professionally managed manner aspects of quality and meaningfulness of the program that refers to the achievement of the objectives of improving professionalism, d) in curriculum development, it is necessary to balance the aspects of content, cognitive, motor, and attitude as well as context aspect, meaning that student learning materials should be selected on the essential and strategic, a cognitive development of students can be more attention, e) standards and practice of student learning outcomes nationally conducted by taking into account the various competencies of students, need to be improved, f) it is necessary to procure textbooks and classroom facilities (media and how to use it), it is related with low book-keeping conditions among students and limited media learning in schools. In addition, this procurement supports the implementation of a curriculum that takes account of aspects of context and cognition in a balanced way. Undoubtedly, if all the above actions are realized then the teaching and learning process (PBM) organized by the school and teachers will work as they should.

\section{B. School and Teacher}

In addition to policymakers, the school as a place for students to learn and teachers as facilitators of students in obtaining literacy also has a very important role in efforts to improve the acquisition of student literacy. Allington and Cunningham [5] suggest that teachers be sensitive to the seven signs of literacy beginning to appear in children; 1) they pretend to do the activity of reading books, poetry, or singing, 2) they write and can read their writing even though no one can read their writings, 3) they can show what they want to read, 4) they already know words and letters , 5) they know some concrete words, their names, names of friends, and other favored words, 6) they recognize intonation of words, and 7) they can mention letters and can name words beginning with initials. When these seven signs of literacy are well recognized, the teacher can maximize his efforts in order to lead the students to acquire their literacy skills embodied in the following actions; a) utilizing learning resources in the school environment to address pedagogical aspects to support the achievement of curricular goals effectively and efficiently; b) using learning resources and instructional media that stimulate students to dare to try complicated things to 
simplify, develop students' creativity by providing opportunities to create freely and responsibly without hindering other academic activities, d) varying learning models that can enhance teachers' creativity in the classroom and students' learning creativity at school and at home, e) providing essential learning materials and (f) provide learning materials that are directly related to students 'real life' (contextual), g) make improvements in terms of assessment of students' daily learning outcomes in the classroom, h) varying the scoring form not only written test of multiple-choice forms but also in other forms, such as self-test, description test etc., i) involving all elements of the school (students, teachers, and school administrators) in decision-making about planning discipline, ordinances of discussion, communication, etc.) without imposing a unilateral will, and $\mathrm{j}$ ) embracing, encouraging, and assisting parents create a favorable environment conducive to the development of early literacy by doing two things; First, make regular contacts and build a close friendship to make parents aware of the specific things they can do and at least for their children; Second, encourage parents to share stories about work, family, or other issues with their children while bathing, accompany the meal, drive them to school, etc. If all points are realized, it is not impossible that the learning and teaching process will run as expected expectations that impact the birth of a literate generation

\section{Parents}

Furthermore, the role of parents is a role that is not less important than the role of schools and teachers. Fitgerald, et al. [4] suggests that there is a possibility of a positive relationship between the level of ability and parental education and the level of appreciation of the literacy environment. The higher the level of parental literacy, the higher their commitment to creating an environment for their children. Students get initial literacy from their home environment. This means that the initial literacy gained by students comes from their parents. Some parents are informed of the importance of a literate environment for the development of children's literacy and they intend to familiarize their children's literacy practice. Others, however, do not succeed in providing the literacy support their child needs. The results of the [10] showed that children whose parents were given treatment of literacy programs in the family had higher literacy skills. The "home literacy" program includes reading books together, supporting writing activities, and creating fun activities at home in learning literacy. Laurent concluded that to do "home literacy", parents and teachers should be directly involved in improving the ability of first-year children's literacy in primary school. This is reinforced by the results of research conducted by [11] that the form of parental involvement is one positive component in increasing the basic literacy of preschool children in almost all countries. He also explained that parental involvement has a positive influence in the development of children's literacy skills.

\section{CONCLUSION}

From the discussion that has been presented in this article, some of the conclusions that can be drawn are as follows. First, based on some definitions of the experts in terms of literacy, it can be concluded that the literacy in the 21 st century is defined as the ability to read, write, view, and design a thing with the ability to think critically that causes someone to communicate effectively and efficiently thus creating meaning. Secondly, the reality of student literacy in Indonesia shows that the literacy ability of Indonesian students is low. This is shown from several studies by PISA and PIRLS that placed students in Indonesia at the bottom 5 in a decade. Third, literacy should not only be interpreted as the ability to read and write alone, but more broadly understanding and meaning. Primary school students in Indonesia continue to be directed to the multiliteracies which requires students to continue to improve the understanding of information in various fields. Fourth, the difficulties faced by elementary school students in improving their language literacy skills are the inadequacy of literacy practices undertaken by teachers, the lack of available literacy environments, and different parental literacy levels that impact on the lack of literacy of information obtained by students from the home. Fifth, in an effort to solve the difficult problem of the students improving their literacy ability, various parties; government, schools and teachers, and parents have an essential role. Each side has roles and responsibilities based on its capacity. The point is, all activities or activities can bring the desire of students to improve literacy skills.

\section{ACKNOWLEDGEMENT}

Thanks to Universitas Muhammadiyah Sidoarjo for supporting this research.

\section{REFERENCES}

[1] Tjalla, Awaluddin. (2011). Potret Mutu Pendidikan Indonesia Ditinjau dari Hasil-hasil Studi Internasional.

[2] Nurdiyanti, Eko \& Suryanto Edy. 2010. Pembelajaran Literasi Mata PelajaranBahasa Indonesia pada Siswa Kelas V Sekolah Dasar. Pedagogia, 13 (2), Agustus 2010.

[3] Gipayana, Muhana. 2004. Pengajaran Literasi dan Penilaian portofolio dalam Konteks Pembelajaran Menulis di SD. Jurnal Ilmu Pendidikan. Februari 2004, Jilid 11, Nomor 1.

[4] Musthafa, Bachrudin. 2014. Literasi Dini dan Literasi Remaja: Teori, Konsep, dan Praktik. Bandung: CREST.

[5] Metiri Group. 2003. Engage 21stCentury Skills: Literacy in the Digital Age. NCREL and Metiri Group : Illinois and California.

[6] Wardana dan Zamzam. (2014). Strategi Peningkatan Kemampuan Literasi Siswa di Madrasah. Jurnal Ilmiah "Widya Pustaka Pendidikan", 2 (3)

[7] Kuder, S. Jay \& Cindi Hasit. 2002. Enhancing Literacy for All Students. USA:Pearson Education Inc.

[8] Amariana, Ainin. 2012. Keterlibatan Orangtua dalam Perkembangan Literasi Anak Usia Dini. Sripsi Universitas Muhammadiyah Surakarta: Tidak Diterbitkan.

[9] Irawan, D., Rachmi, C., Irawan, H., Abraham, J., Kusno, K., Multazam, M., Rosada, K., Nugroho, S., Kusumah, G., Holidin, D., \& Aziz, N. (2017). Penerapan Open Science di Indonesia agar riset lebih terbuka, mudah Diakses, dan Meningkatkan Dampak Saintifik. Berkala Ilmu Perpustakaan dan Informasi, 13(1), 25-36. 
/*doi:http://dx.doi.org/10.22146/bip.17054*/ doi:https://doi.org/10.22146/bip.17054

[10] Laurent, Lise Saint, dkk. 2005. Effect of Family Literacy Program Adapting ParentalIntervension to First Grader's Evolution of Reading and Writing Abilities. Journal of Early Childhood Literacy.

[11] Park, Hyunjoon. 2008. Home Literacy Environment and Children's Reading Performance: A Comparative Study of 25 Countries. Educational Research and Evaluation, 14 (6), Desember 2008. 